\title{
Sistem Informasi Penerimaan Berkas Badan Usaha Jasa Konstruksi pada Lembaga Pengembangan Jasa Konstruksi (LPJK) Provinsi Maluku Utara
}

\author{
Tri Hardiah Ningrum ${ }^{1}$, M. Kasyif G. Umar ${ }^{2}$, Subhan ${ }^{3}$ \\ Program Studi Manajemen Informatika \\ Akademi Ilmu Komputer Aikom Ternate \\ trihardiahnigrum@gmail.com
}

\begin{abstract}
Abstrak
Perkembangan teknologi Sistem informasi pada saat ini menjadi suatu pendukung dalam suatu kegiatan atau pekerjaan. Keberadaan sistem informasi sudah menjadi kebutuhan dasar bagi suatu instansi dalam segala aspek aktifitas. Sistem informasi juga berperan sebagai alat bantu dalam menyelesaikan suatu permasalahan yang ada dalam lingkungan pekerjaan.Tujuan dari pembuatan sistem informasi penerimaan berkas badan usaha jasa konstruksi LPJK Provinsi Maluku, tersebut untuk mempermudah user dan membantu staf dalam pengelolaan data berkas di kantor LPJK. Proses pembuatannya mengunakan Bahasa Pemogramaan visual basic.net dan Microsoft access sebagai databasenya dalam pembuatan sertifikasi berkas badan usaha, berkas registrasi tahun ke-2 dan berkas registrasi tahun ke-3, berkas perpanjangan serta berkas perubahan. Dan dikembangkan sistem informasi penerimaan berkas badan usaha jasa konstruksi yang memungkinkan user tidak kesulitan dalam mengelola berkas, dari mulai penginputan data berkas. Sehingga dengan adanya sistem informasi ini, proses penerimaan berkas badan usaha jasa konstruksi sudah tidak lagi dilakukan secara konvensional seperti yang pernah diterapkan sebelumnya.
\end{abstract}

\section{Kata Kunci: Sistem Informasi, Penerimaan Berkas, Visual Basic.Net}

\begin{abstract}
The development of technology Information systems at this time become a supporter in an activity or job. The existence of an information system has become an essential requirement for an agency in all aspects of operations. The information system also serves as a tool in solving a problem that exists in the work environment. The purpose of making information systems for acceptance of the LPJK construction service company in Maluku Province is to facilitate users and assist staff in managing file data at the LPJK office. The manufacturing process uses Visual Basic.net programming language and Microsoft Access as its database in making certification of business entity files, registration files for the second year and registration files for the third year, extension files and amendment files. And developed a filing receipt service information system construction service business that allows users no difficulty in managing files, from inputting file data. So with the existence of this information system, the process of receiving construction service business entity files is no longer carried out conventionally as previously applied.
\end{abstract}

Keywords: Information Systems, File Receipts Visual Basic.Net 
PENDAHULUAN

Sistem Informasi juga berperan sebagai alat bantu dalam menyelesaikan suatu permasalahan yang ada dalam lingkungan pekerjaan. Penerapan sistem Informasi juga berperan penting pada instansi yang bekerja dibidang jasa pelayanan. Kantor Lembaga Pengembangan Jasa Konstruksi (LPJK) Provinsi Maluku Utara merupakan jasa konstruksi yang berperan penting bagi masyarakat dalam bidang jasa konstruksi pelaksanaan pengembangan jasa konstruksi sebagaimana yang di atur pada dalam Pasal 31 Ayat (3) Undang-Undang Nomor 18 tahun 1999 tentang Jasa Konstruksi beserta peraturan pelaksanaanya yang lebih rinci di atur dalam Peraturan Pemerintah Nomor 28 tahun 2000 tentang Usaha dan Peran Masyarakat Jasa Konstruksi (Parlem. 2017. Kumpulan Peraturan LPJK Nasional Tentang Registrasi Usaha Jasa Konstruksi, Balai Krida: Kebayoran Baru Jakarta Selatan). Proses penerimaan berkas pada jasa pelayanan badan usaha jasa konstruksi saat ini masih terdapat permasalahan dalam proses manajemen pemberkasan. Permasalahan tersebut diantaranya dalam proses pemberkasan atau dokumen dan pencarian dokumen yang masih dilakukan secara konvensional, dalam hal ini adalah pembuatan Sertifikasi berkas badan usaha, berkas registrasi tahun ke-2 dan berkas registrasi tahun ke-3, berkas perpanjangan serta berkas perubahan.

Maka dengan adanya sistem Informasi yang akan di rancang ini bertujuan nanti dapat mempermudah user atau pengguna dalam mengelolah penerimaan berkas sehingga tidak menyulitkan staf dalam pencarian berkas atau dokumen ulang ketika berkas tersebut di butuhkan.
Berdasarkan hal tersebut, maka peneliti tertarik untuk melakukan penelitian dan pembuatan sistem Informasi yaitu Tugas Akhir (TA) dengan tujuan mengembangkan sistem yang ada saat ini. Oleh karena itu, peneliti mengangkat penelitian dengan judul "Sistem Informasi Penerimaan Berkas Badan Usaha Jasa Konstruksi Pada Lembaga Pengembangan Jasa Konstruksi (Lpjk) Provinsi Maluku Utara".

\section{Rumusan Masalah}

Berdasarkan latar belakang diatas, maka yang menjadi pokok permasalahan yaitu; bagaimana merancang penerimaan berkas baru pada Badan Usaha Jasa Konstruksi pada Lembaga Pengembangan Jasa Konstruksi (LPJK) Provinsi Maluku Utara

\section{Tujuan Penelitian}

Tujuan dari pelaksanaan penelitian ini adalah untuk membuat Sistem Informasi Penerimaan Berkas Badan Usaha Jasa Konstruksi pada Lembaga Jasa Konstruksi (LPJK) Provinsi Maluku Utara.

\section{Manfaat Penelitian}

Adapun beberapa manfaat dari penelitian ini antara lain:

1. Bagi ilmu pengetahuan

Diharapkan dengan adanya penelitian ini maka akan menjadi kajian pustaka dan landasan bagi para peneliti.

2. Bagi Mahasiswa

Untuk dapat menambah wawasan dan pengetahuan peneliti tentang bagaimana merancang dan membuat aplikasi sistem Informasi.

3. Bagi Instansi

Memberikan kemudahan bagi pegawai pemakai atau user dalam mengelolah verifikasi dan validasi berkas badan usaha. 


\section{Tinjauan Pustaka}

Pada penelitian yang dilakukan oleh (Fahrizal Halim, 2006) dalam Penelitiannya Tentang Sistem Informasi dan Database Registrasi Tenaga Kerja Konstruksi pada Lembaga Pengembangan Jasa Konstruksi Daerah (LPJKD) Provinsi Maluku Utara dalam penelitian ini menggunakan bahasa pemograman Paradox 7 sebagai aplikasi basis data standar yang biasanya menggunakan bahasa pemograman Delphi sebagai Interfacenya dan Borland Delphi 5.0 sebagai program berbasis Obyek Pascal Delphi juga memberikan fasilitas pembuatan aplikasi Visual seperti halnya Visual Basic.

Pada penelitian yang dilakukan oleh (Bayu Rianto, 2018) dalam penelitiannya tentang Perancangan Aplikasi Pengolahan Data Berkas Pajak pada KPP Pratama Pekan Baru Berbasis Desktop. Dalam penelitian ini menggunakan bahasa pemograman MySQL sebagai Databasenya untuk pembuatan laporannya penelitian ini memiliki tujuan utama agar terbangunnya sistem Informasi yang dapat digunakan dalam sistem pengarsipan dan pencarian berkas, diharapkan dengan adanya sistem ini memaksimalkan pekerjaan pegawai agar dalam penyampaian Informasi, ketelitian maupun volume pekerjaan dapat ditangani lebih efesien dan efektif.

Penelitian yang dilakukan oleh (Mirza Abdillah dkk, 2017) dengan judul Sistem Informasi Penerimaan Berkas Usul Kenaikan Pangkat pada Badan Kepegawaian Daerah Kabupaten Kutai Kartanegara dalam penelitian ini yang dilakukan oleh Mirza Abdillah bertujuan yaitu merancang dan membuat suatu sistem Informasi untuk mempermudah proses awal penerimaan berkas usul kenaikan pangkat, sistem dibuat menggunakan metode Waterfall dengan bahasa pemrograman PHP dan HTML.

Pada penelitian yang dilakukan oleh (Dahlan Abdullah $d k k, 2014)$ dalam penelitiannya tentang Perancangan Sistem Informasi Pendataan Siswa SMP Islam Darul Yatama. dalam penelitian ini berbasis Web dengan menggunakan bahasa pemograman $P H P$, dan $M Y S Q L$ dalam penulisan ini selain memaparkan kajian teori yang digunakan sebagai dasar penyusunan juga akan dibahas mengenai perancangan sistem infornasi berbasis Web dengan menggunakan $P H P$ dan $M y S Q L$. Sehingga diharapkan dapat memperbaiki segala kekurangan pada sistem lama.

Pada penelitian yang dilakukan oleh (Fico Setiawan dkk, 2013) dalam penelitiannya tentang Analisa dan Perancangan Sistem Informasi Pengarsipan Berkas Pertanggungjawaban Anggaran APBD pada Dinas Pemuda dan Olahraga Provinsi Kepulauan Bangka Belitung dalam penelitian ini menggunakan metode berorientasi objek dengan pemodelan Unified Modeling Language (UML) dan menggunakan Tools Rational Rose. Penelitian ini menghasilkan desain sistem Informasi pengarsipan yang mampu menghasilkan Informasi yang cepat dan akurat bagi pengambilan keputusan.

Dari sistem Informasi yang telah dijelaskan dari beberapa para ahli dengan menggunakan dengan bahasa pemograman Delphi dan Paradox $7 \mathrm{Php}$ dan MySQL berbasis Web sedangkan perbedaannya dengan sistem Informasi yang digunakan oleh peneliti yaitu Visual Basic.Net dan Microsoft Accsess sebagai Database dengan judul Sistem Informasi Penerimaan Berkas Badan Usaha Jasa Konstruksi pada 
Lembaga Pengembangan Jasa Konstruksi (LPJK) Provinsi Maluku Utara.

\section{LANDASAN TEORI Pengertian Sistem}

Sistem pada umumnya yaitu merupakan kumpulan dari sub-sub sistem yang saling berinteraksi antara sub sistem yang satu dengan sub sistem yang lain dalam mencapai tujuan yang sama.

Sistem adalah suatu jaringan kerja dari prosedur-prosedur yang saling berhubungan, berkumpul bersama-sama untuk melakukan suatu kegiatan atau menyelesaikan suatu sasaran tertentu (Jogiyanto, 2005).

Sistem adalah seperangkat elemen yang membentuk kagiatan atau suatu prosedur atau bagian pengelolahan yang mencari suatu tujuan atau tujuan-tujuan bersama dengan mengoperasikan data atau barang pada waktu tertentu untuk menghasilkan Informasi atau energi atau barang (Murdick, 1993).

Sistem adalah kombinasi antara prosedur kerja, Informasi, orang dan teknologi Informasi yang diorganisasikan untuk mencapai tujuan dalam sebuah organisasi. Sistem Informasi selalu menggambarkan, merancang, mengimplementasikan dengan menggunakan proses perkembangan sistematis dan merancang sistem Informasi berdasarkan analisa kebutuhan (Kadir, 2008).

\section{Pengertian Informasi}

Informasi merupakan kelompok teratur, studi yang mewakili kuantitas tindakan benda dan sebagainya. data berbentuk karakter yang terdapat berupa alfabet, angka maupun simbol-simbol khusus (Davis, 1992).

\section{Pengertian Berkas}

Berkas adalah merupakan file atau dokumen yang berisi sebuah kumpulan Informasi atau media penyimpanan dokumen. Yang Menyimpan data dari file tertentu.

Visual Basic.Net atau VB.NET adalah bagian dari bahasa pemrogramman tingkat tinggi VB.NET merupakan bagian dari penyederhanaan bahasa pemrogramman pada platform.NET yang mengadopsi sintak Visual Basic.

\section{Pengertian Visual Basic.Net}

Visual Basic.Net merupakan sebuah alat untuk mengembangkan dan membangun aplikasi bergerak di atas sistem NET Framework, dengan menggunakan bahasa BASIC dan dengan menggunakan alat ini para programmer dapat membangun aplikasi Windows Form, dan juga aplikasi Command line.

\section{Pengertian Microsoft Access}

Microsoft Access adalah merupakan salah satu software pengolah Database yang berjalan di bawah sistem windows. Microsoft Access merupakan salah satu produk Office dari Microsoft yang dapat menangani Database dengan skala besar maupun kecil. dalam pengolahan Database, Microsoft Access ini memiliki sarana atau objek-objek yang dapat mempermudahkan pekerjaan bagi pengguna.

\section{METODE PENELITIAN}

Metode yang digunakan dalam penelitian ini adalah peneliti kasus atau lapangan yang bertujuan untuk mempelajari secara intensif latar belakang keadaan sekarang dan interaksi lingkungan suatu obyek, dengan menggunakan metode pengumpulan data sebagai berikut. 
1. Observasi: Dilakukan dengan cara mengamati sistem yang berjalan.

2. Wawancara: mengumpulan data dengan cara dilakukan tanya jawab kepada stake holder.

3. Studi Literatur: pengumpulan data menggunakan dokumen atau referensi baik berupa hardcopy maupun softcopy seperti buku, makalah, UndangUndang, Peraturan Pemerintah, Peraturan Lembaga.

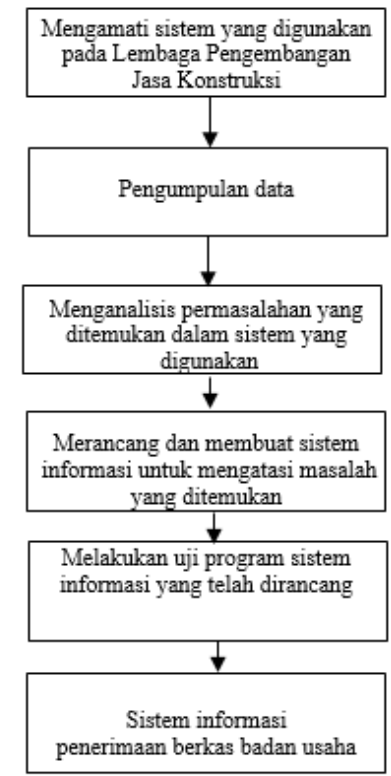

Gambar 1. Kerangka Berpikir

\section{ANALIS DAN PERANCANGAN}

Sistem komputerisasi ini di rancang untuk memudahkan user dalam membuat atau mengelolah berkas serta mencari arsip atau file yang kemudian diproses secara komputerisasi sehingga menghasilkan output yang cepat dan akurat, dimana berkas tersebut di simpan dalam Database yang kemudian di proses secara cepat dan akurat.

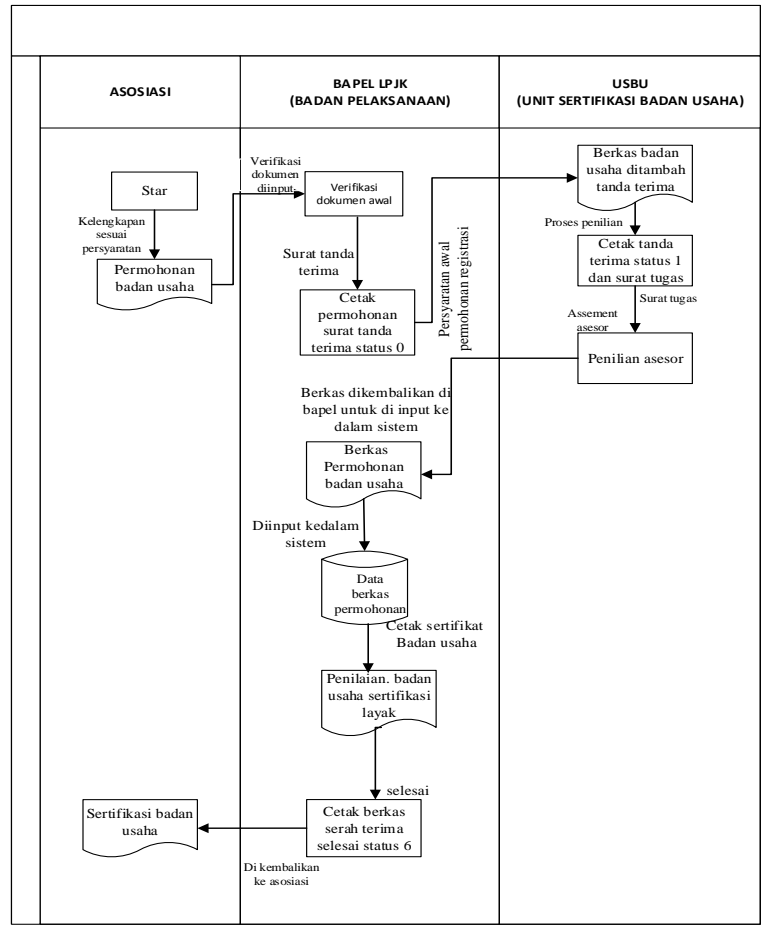

Gambar 2. Analisis Yang Diusulkan

\section{Diagram Konteks}

Diagram konteks merupakan tahap pertama dari bagian Flow Diagram (DFD) yang berfungsi memetakan model lingkungan, yang dipresentasikan dengan lingkungan tunggal yang mewakili keseluruhan sistem. Diagram konteks dimulai dengan menggambarkan terminator, aliran data, control, penyimpanan dan proses tunggal yang mempresentasikan keseluruhan sistem. Pada Sistem Informasi Penerimaan Berkas pada Lembaga Pengembangan Jasa Konstruksi (LPJK) Provinsi Maluku Utara sebagai berikut :

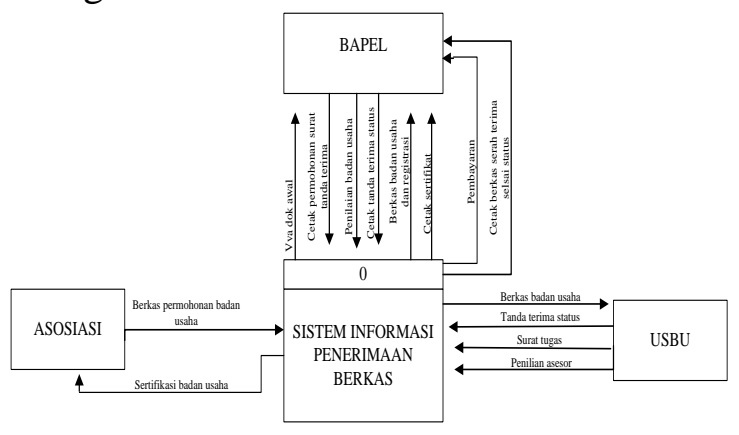

Gambar 3. Diagram Konteks 
Dari diagram konteks diatas dapat diketahui hubungan sistem dengan lingkungannya yang mendukung peran dalam menjalankan sistem. Pada Sistem Informasi Penerimaan Berkas pada Lembaga Pengembangan Jasa Konstruksi Provinsi Maluku Utara entitas yang terlibat dalam sistem adalah Asosiasi, Badan Pelaksanaan, Unit Sertifikasi Badan Usaha, Pengurus LPJK sedangkan sistem Informasi penerimaan berkas pada Lembaga Pengembangan Jasa Konstruksi Provinsi

Maluku Utara adalah sebagai proses pengolahan sistem Informasi.

\section{DAD Level 0}

DAD Level 0 adalah diagram yang mengambarkan secara keseluruhan dari proses arus data yang berjalan.

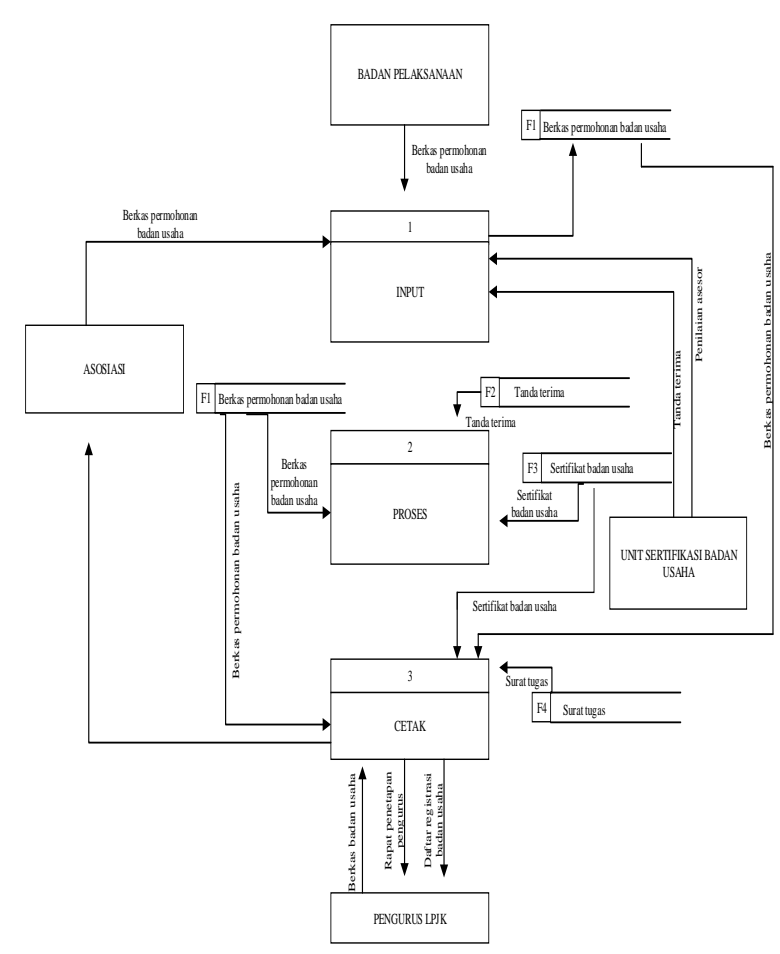

Gambar 4. DAD Level 0

\section{DAD Level 1}

Dari diagram konteks diatas, maka dapat dijabarkan lebih rinci menjadi diagram arus data level 1 (satu). Pada diagram level 1. Akan terbagi menjadi dua kelompok proses, yaitu Proses Input Data dan Proses Percetakan.

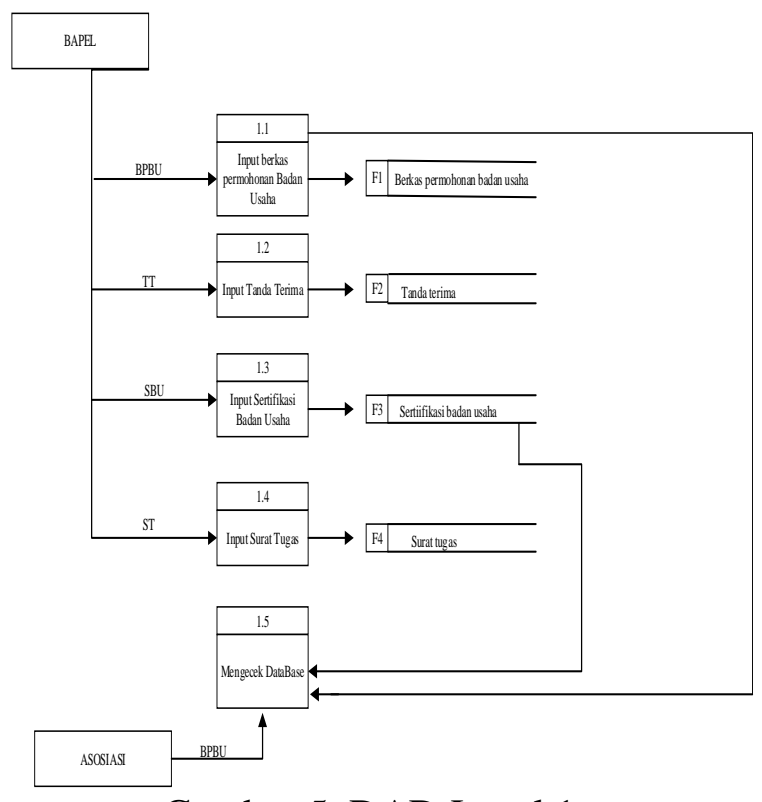

Gambar 5. DAD Level 1

\section{DAD Level 2}

Dari diagram level 1 (satu), maka dapat dijabarkan lebih rinci menjadi diagram arus data level 2 (dua). Pada diagram level 2 (dua), masing-masing proses dilaksanakan lebih rinci.

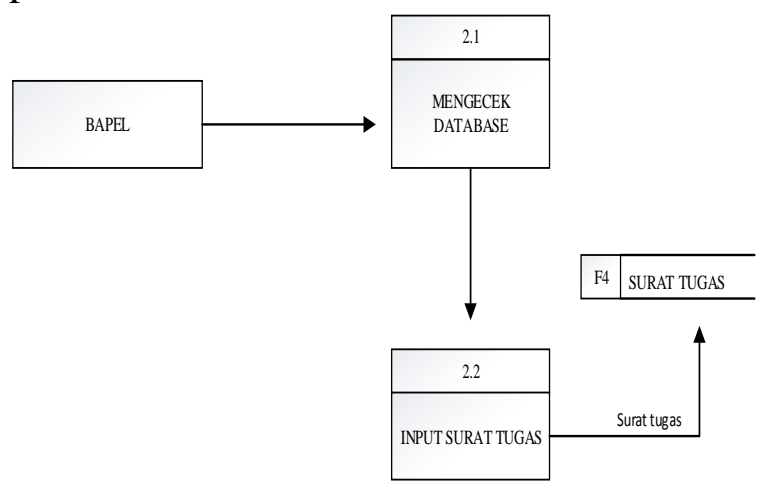

Gambar 6. DAD Level 2

\section{DAD Level 3}

Dari penjelasan diagram konteks dari DAD level 0, level 1 dan level 2 serta Level 3 lebih terperici dari masing-masing proses dilaksanakan lebih rinci. 


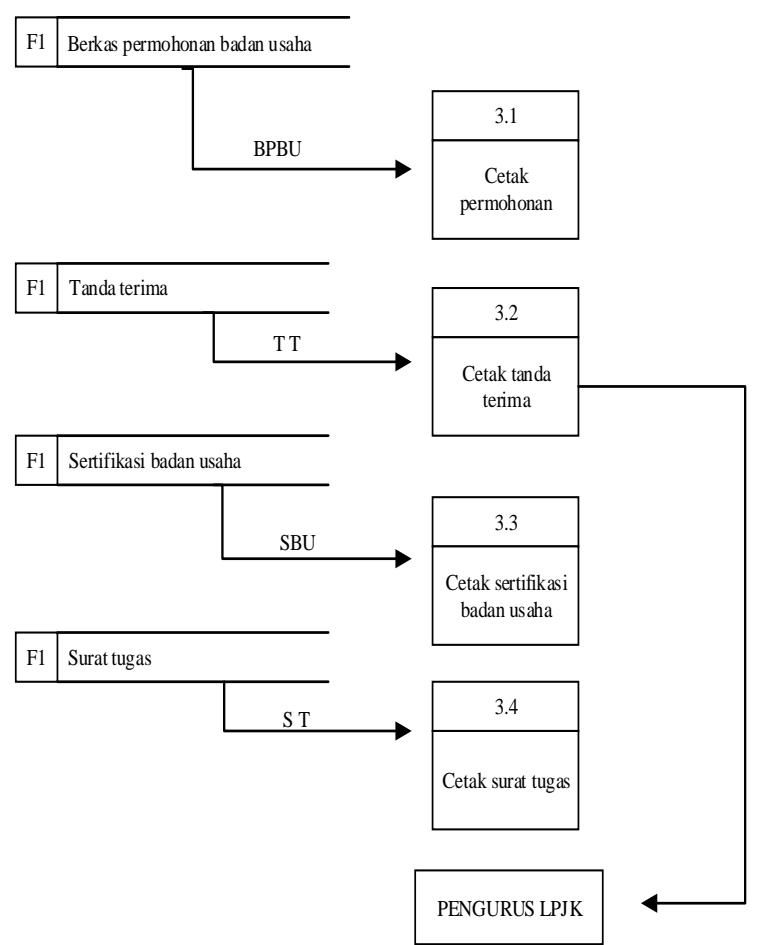

Gambar 7. DAD Level 3

\section{IMPLEMENTASI DAN PEMBAHASAN}

Pertama masuk ke sistem melalui proses login sehingga yang berhak menggunakan sistem adalah user yang telah terdaftar pada sistem.

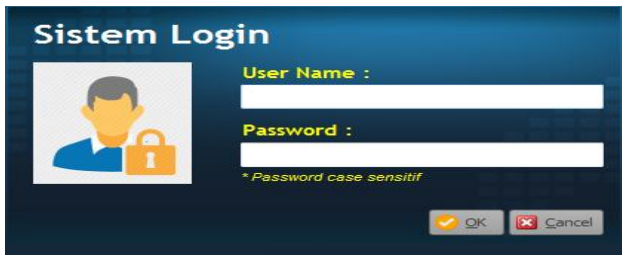

Gambar 8. Tampilan Form Login proses kedua adalah ini tampilan menu form utama pada sistem pengolahan berkas

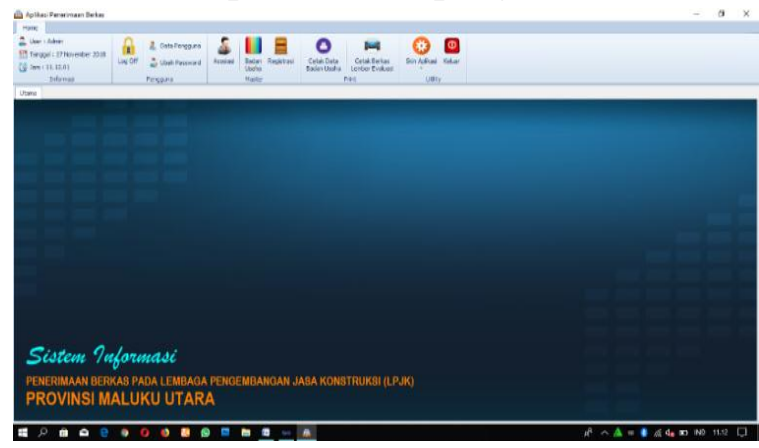

Gambar 9. Tampilan Form Menu Utama

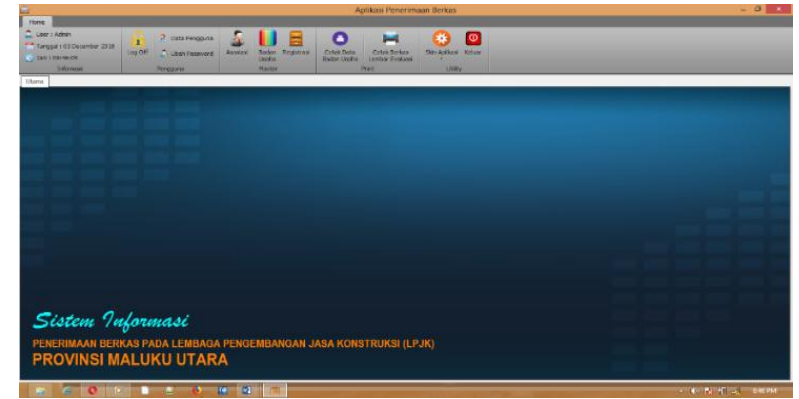

Gambar 10. Tampilan Form Input Data Asosiasi

Proses ketiga adalah masuk ke data asosiasi untuk menginput data ke sistem pengelohan data yang terdiri dari kode Asosiasi, Nama Asosiasi, Alamat, No.Telp, E-mail. Website.

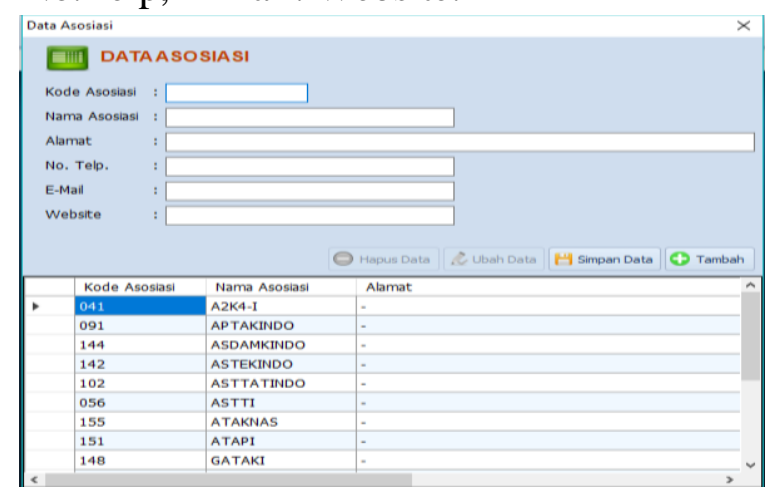

Gambar 11. Tampilan Form Input Data Asosiasi

Proses ke empat adalah masuk ke data Pengguna untuk menginput data ke sistem pengelohan data yang terdiri dari: kode pengguna, nama lengkap, nama pengguna, password, ulangi password

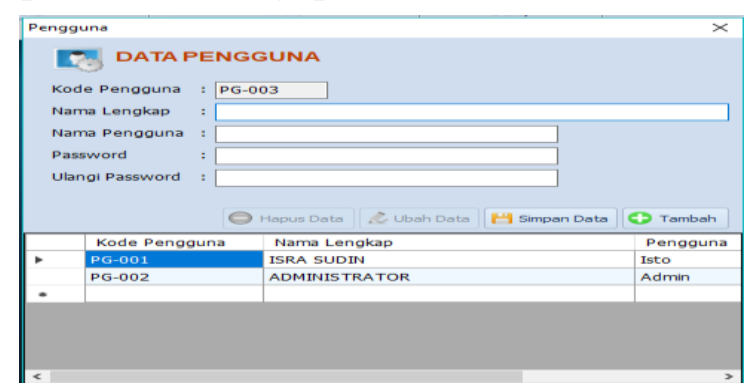

Gambar 12. Tampilan From Input Data

\section{Skin}

Proses ke empat adalah masuk ke data skin yang ada pada tampilan form diatas untuk mengubah tampilan atau backround sistem. 
Proses ke lima adalah masuk ke data registrasi untuk menginput data ke sistem pengelohan data yang terdiri dari: nomor berkas, proses, asosiasi, nama badan usaha, direktur, NPWP, klasifikasi

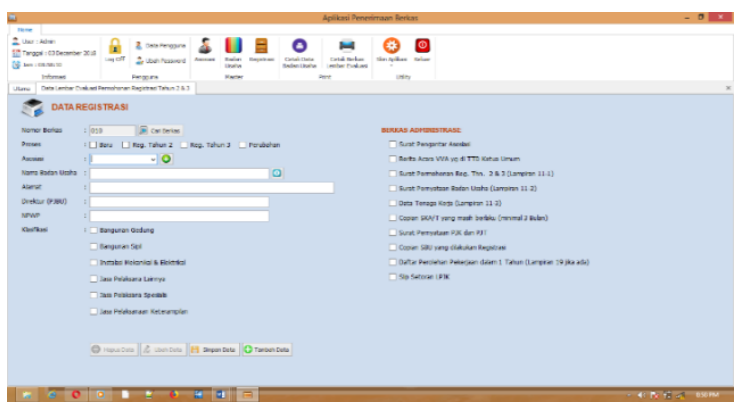

Gambar 13. Tampilan Hasil From Input Registrasi

Proses yang ke enam adalah hasil output dari form registrasi berkas berupa

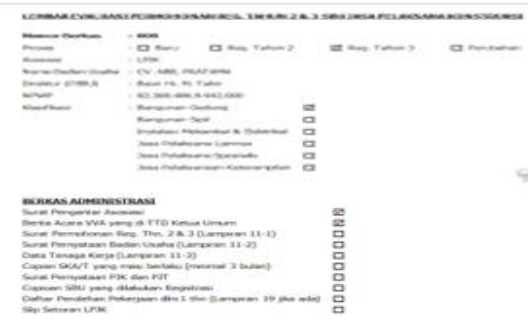

lembar evaluasi permohonan badan usaha Gambar 14. Hasil Output Lembar Evaluasi

\section{KESIMPULAN}

1. Dengan adanya sistem Informasi penerimaan berkas badan usaha pada Lembaga Pengembangan Jasa Konstruksi (LPJK) provinsi Maluku utara bisa membantu user dalam mengelolah verivikasi data lebih cepat, tepat dan akurat sehingga menghemat waktu dan tenaga dibandingkan sistem manual yang membutuhkan waktu sangat lama.

2. Dengan adanya pemanfaatan teknologi Informasi yang berkembang saat ini bisa menjadi meningkatkan kinerja bagi user dalam mengelolah data badan usaha, data registrasi tahun ke-2 dan data registrasi tahun ke-3, data perpanjangan serta data perubahan lebih cepat dan tepat

\section{Saran}

1. Diperlukan pengembangan sistem berjalan secara otomatis sehingga tidak menjadi keterlambatan, atau pencarian dan penginputan data tentang penerimaan berkas

2. perlu adanya kedisiplinan dan kerja sama yang tinggi sehingga tidak menumpuk pekerjaan yang ada.

\section{DAFTAR PUSTAKA}

Anonim, (2018). (http://www.lpjk.org/mo dules/tentang_lpjk.php selasa 25 april $201810.52 \mathrm{am})$

Anonim,(2018).(https://www.scribd.com/d oc/219576286/Klasifikasi-Bidang-

Dan-Sub-Bidang-Usaha-JasaPelaksana-Konstruksi-Sesuai-

Peraturan-LPJK-No-10-Thn-2013 selasa 25 april $201810.52 \mathrm{am})$.

Anonim,(2018).(http://www.academia.edu/l 9604665/PengertianSistem_Informasi_ Menurut_Para_Ahli rabu 24 Mei 11.30 am.

Anonim,(2018).(http://Www.Sisilain.Net/201 2/11/Pengertian-Dan-Fungsi-VisualBasic.Html Rabu 24 Mei 2018 13.00).

Anonim,(2018).(https://www.scribd.com/doc /102259326/Pengertian-MicrosoftAccess rabu 24 Mei $201813.00 \mathrm{am})$.

Anonim, lpjk.net Selasa 6 November (2018) $13.30 \mathrm{am}$.

Abdillah Mirza, (2017) Sistem Informasi Penerimaan Berkas Usul Kenaikan Pangkat pada Badan Kepegawaian Daerah Kabupaten Kutai Kartanegara.

Abdullah Dahlan, (2014) Perancangan Sistem Informasi Pendataan Siswa SMP ISLAM DARUL YATAMA.

Abhar Rita dan Suharti (2010) Laporan TA Sistem Informasi Kasus Perdata Pada Pengadilan Negeri Ternate. 
Al Fata, Hanif. Analisa \& Perancangan Sistem Informasi. (2007).

Davis, G. B. (1991). Kerangka Dasar Sistem Informasi Manajemen Bagian 1, Jakarta: PT. Pustaka Binamas Pressindo.

Hasan M. Sumyati dan Sujarwani (2010) Laporan TA Sistem Informasi Manajemen Arsip Pada Sma Negeri 1 Ternate.

Ir. Yuniar Supardi dan M.Ridwan, S.Kom., M.T. Mudah dan cepat membuat program skripsi dengan VB2010/VB2012.

Jogiyanto, H. M. (1999). Analisa dan Sistem Informasi.Penerbit Andi, Yogyakarta, 5.

Jogiyanto, H. M. (2005). Analisis dan desain Sistem informasi. Yogyakarta: Andi Offset.

Jogiyanto, H. M. (2005). Analisa Dan Perancangan Sistem.

Kadir, A. (1999). Konsep \& Tuntunan Praktis Basis Data. Penerbit Andi.

Kusrini, M.Kom, (2006) Strategi Perancangan Dan Pengelolaan Basis Data.

Lee Christoper, (2010), Microsoft access 2010 for beginners jakarta

Lucas, Henry C. "Jr (1993)." Analysis Desain dan Implementasi Sistem Informasi.

Materi KKPI kelas XII A: September 2012. https://indahputriyana.blogspot.com/ 2012/09/ (diakses Desember 2019)

Murdick, R. (1993). Perancangan dan Pembangunan Sistem Informasi. Penerbit Andi, Yogyakarta.

Parlem, (2007), Kumpulan Peraturan LPJK Nasioanal Tentang Registrasi Usaha Jasa Konstruksi.

Parlem, (2005), Sertifikasi dan Registrasi Tenaga Ahli lembaga pengembangan jasa konstruksi.

Rizal Halim, (2006) Sistem Informasi Tenaga Kerja Konstruksi Pada Lembaga Pengambangan Jasa Konstruksi Daerah (LPJKD) Provinsi Maluku Utara.
Rianto Bayu, (2018) Perancangan Aplikasi Pengolahan Data Berkas Pajak pada KPP Pratama Pekan Baru Berbasis Desktop.

Setiawan Fico, (2013) Analisa dan Perancangan Sistem Informasi Pengarsipan Berkas Pertanggungjawaban Anggaran APBD pada Dinas Pemuda dan Olahraga Provinsi Kepulauan Bangka Belitung.

Sangate Novita. dan Ningrum Tri Hardiah, (2018) Laporan PKL AIKOM Ternate.

Winarno, W. W. (2004). Sistem Informasi Manajemen. Yogyakarta: UPP STIM $Y K P N$. 